\title{
The Moldovan Military Academy: Transforming Officer Education
}

\author{
John F. Troxell ${ }^{*}$
}

\section{Professional Military Education in Context}

The twenty-first century has ushered in an era of dynamic changes to the international security environment, which demands new capabilities and responses to new threats, an increased likelihood of operating as part of a multinational effort, combined with an expectation of economic austerity that places downward pressure on defense budgets. This dynamic security environment holds true for superpowers, like the United States, and nations at the other end of the geopolitical spectrum, like the Republic of Moldova. When it comes to the needs of military establishments across the entire range of national size and resources, they all share the same imperative for leader development and professional military education. General Martin Dempsey, Chairman of the U.S. Joint Chiefs of Staff, highlighted this imperative in his recently published "Strategic Direction to the Joint Force." He identified the need to "reinforce leadership development at all levels of Joint Professional Military Education," in order to develop principled leaders "who can combine new capabilities in new ways in complex environments." All nations need to reform and leverage their professional military education programs.

From the perspective of the United States and NATO, a second imperative relates to the efforts undertaken to assist other nations in the enhancement of their professional military education programs. A key tenet of the recently published U.S. defense guidance, Sustaining U.S. Global Leadership: Priorities for $21^{\text {st }}$ Century Defense, is building partnership capacity. ${ }^{2}$ Previous strategic documents have also stressed the importance of activities designed to enhance the professionalization of partner military forces, and former U.S. Secretary of Defense Robert Gates, in a Foreign Affairs article titled "Helping Others Defend Themselves," further elaborated on this concept by emphasizing the importance of building the institutional capacity or human capital of partner nations. ${ }^{3}$ The "Summit Declaration on Defense Capabilities," from the Chicago NATO Summit in 2012, also highlighted the importance of linkages with partner countries and

John Troxell is the academic co-lead of the DEEP-Moldova initiative, and a Research Professor, Strategic Studies Institute, at the U.S. Army War College in Carlisle, PA.

1 Gen. Martin Dempsey, "Chairman's Corner: Strategic Direction to the Joint Force," 6 February 2012; available at www.defense.gov/News/NewsArticle.aspx?ID=67077.

2 Sustaining U.S. Global Leadership: Priorities for $21^{\text {st }}$ Century Defense (Washington, D.C.: U.S. Department of Defense, 5 February 2012); available at http://www.defense.gov/news/ defense_strategic_guidance.pdf.

3 Robert M. Gates, "Helping Others Defend Themselves," Foreign Affairs (May/June 2010); available at www.foreignaffairs.com/articles/66224/robert-m-gates/helping-others-defendthemselves. 
the need to expand education and training. ${ }^{4}$ Partnership capacity building, in part, should be focused on providing assistance to partner and allied professional military education (PME) programs. It is through enhanced partner capacity, and the ability to operate in a multinational environment, that global security challenges will be addressed and global stability will be maximized.

\section{The Moldovan Experience}

The Defense Education Enhancement Program in Moldova was initiated at the invitation of then-President Voronin to the NATO Secretary-General in April 2008, requesting assistance to "gradually bring the curriculum [of the Military Institute] in line with Western standards," as one of their key Individual Partnership Action Plan (IPAP) objectives. When Moldova gained independence from the Soviet Union in 1991, the republic contained no residual military institute or educational infrastructure. The foundation for professional military education (PME) in the Republic of Moldova was based on the Soviet model, and the national leadership acknowledged that they needed to transition from this era. The Military Institute was created in 1992, and began with a two-year pre-commissioning course of instruction. In 1996 the curriculum expanded to a three-year program, and expanded to the current four-year program in 2002, graduating the first "four-year" class in 2006. The four-year curriculum is in accordance with the education law of Moldova and the 1999 Bologna Agreements as a Level I licensure and diploma (Bachelor's degree) granting institution.

Responding to the request from President Voronin, NATO organized a multinational team of military professionals and educators to conduct an assessment visit in January 2009 to review the education and training capabilities of the Military Institute of the Moldovan Armed Forces. The assessment included reviewing existing curricula for the basic course, the combined arms advanced course, and the junior staff officers' course, and exchanging views on future curricula for senior officers' staff courses. The major recommendations included adjustments to the existing four-year Bachelor's degree basic course (Level I) related to the objective of creating "citizen-soldiers." These adjustments called for the incorporation of additional courses on leadership, civil-military relations, and other related topics. This effort would be designed to modernize the curriculum and include NATO/Western elements. The ultimate goals for the curriculum were to create leaders that are open to the society they defend, comfortable with the media, and know at least one foreign language. The Military Institute was also encouraged to develop a program of instruction for teaching methodologies for educators, teachers, and trainers.

The most ambitious recommendation was to develop a senior officers course, including a Master's degree (Level II) program. At the time of the assessment visit, there was no additional military education available in Moldova beyond the junior staff officers' course. Members of the Military Institute expressed the concern (validated by the

4 NATO Press Release, "Summit Declaration on Defense Capabilities: Toward NATO Forces 2020," 20 May 2012; available at http://www.nato.int/cps/en/natolive/official_texts_ 87594.htm?mode=pressrelease. 
highest levels in the Moldovan Ministry of Defense) that career officers needed additional opportunities for both higher-level military studies and related civilian opportunities to gain a Master's degree. Consequently, in accordance with the Moldovan education law and the Bologna Accords, they proposed (and the assessment team agreed) to explore the possibility of creating a Level II program in Military Art and Science and in National Security or Defense Studies. This program would require approximately eighteen months of study, and would be open to senior officers (Lieutenant Colonels) and senior civilian members of the national security departments of the national government (such as the Ministry of Defense and Ministry of Foreign Affairs).

The final recommendation concerned the development of a Center for Strategic and Security Studies. This center would focus on the development of concepts and doctrine for the Moldovan armed forces and represent a synergistic use of faculty and resources associated with an enhanced Military Institute.

Several months later, in May 2009, another multinational team returned to the Republic of Moldova, and working with the staff and faculty of the Military Institute developed both a long-range plan and a detailed action plan for the succeeding year. A depiction of the long-range plan, as executed, appears below.

In keeping with the long-range plan, the execution of this DEEP involved the development of detailed annual action plans (a sample action plan is included below in Table 1 ), which were initially focused on program development, curriculum development, and

\section{Military Education Action Plan for DEEP-Moldova: Military Academy of the Republic of Moldova}

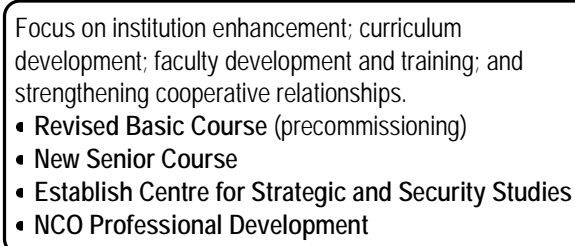

- NATO Team Academic Review \& Assessment May'10 (Roadmap and Action Plan)

- Curriculum development workshop, Jan'11

- Multiple lecture and curriculum development visits, Sep'10 to Apr'11

- NPS support to Research Center, Mar'11

- Familiarization visits, Feb \& Mar'11

- Teaching methodology workshop, Jun'11

- Assessment, Jan'09

- Plan development, May'09

- NATO Team Academic Review, Nov'09

- Bilateral-Defense Consultation

endorsement, Jan'10

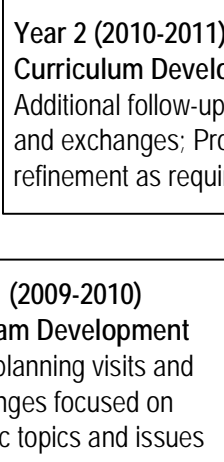

\begin{tabular}{|l|}
\hline Year 3 (2011-2012+) \\
Continued follow-up \\
and coordination \\
Movement toward \\
self-sufficiency \\
Plan for Sustainment \\
\hline
\end{tabular}

New courses initiated - 1st yr Basic Course

- Senior Course

- NCO courses

- AAR conducted

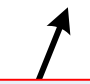

New courses developed

- Approved by MOD and MOE

- Research Center established

Figure 1: Long-Range DEEP Plan for Military Education Reform in Moldova. 
faculty development. In addition to workshops related to these three topics, more focused events were conducted to both educate faculty and assist them in the development of specific courses that were called for by the enhanced academic programs. These included leadership, globalization, civil-military relations, media and communications, elements of military science, and several others. In addition to events coordinated or conducted by DEEP team members, other supporting activities included advanced distributed learning workshops, teaching methodology workshops, NATO School courses for faculty development, and programs offered by the Bureau for International Language Coordination. Several faculty familiarization visits were also arranged with comparable military education institutions in Romania, such as the Romanian National Defense University, and in the United States, including the Maneuver Center of Excellence at Ft. Benning, Georgia, and the Command and General Staff College, at Ft. Leavenworth, Kansas.

At the end of each year a detailed after action review (AAR) was conducted, often in conjunction with the NATO IPAP review process. In each case, the AAR was supported by the key members of the multinational team and the staff and faculty of the Military Institute. The next year's action plan was fine-tuned by applying the lessons learned concerning the scheduling of visits to maximize interaction time with faculty and students, and taking advantage of the evolving needs of the faculty as they further developed their curriculum as well as the opportunities that were made available by different supporting institutions and nations.

Table 1: Sample Action Plan (Moldova Military Institute Action Plan 2010-2011, as of 20 July 2010).

\begin{tabular}{|c|c|c|c|c|c|c|}
\hline$\#$ & Date & Event & Participants & Project & Funding & Status \\
\hline 1 & $\begin{array}{l}28 \text { Jun- } \\
1 \text { Jul } \\
2010\end{array}$ & $\begin{array}{l}\text { Lecture \& Curriculum } \\
\text { Development Session } \\
\text { I: International Security }\end{array}$ & $\begin{array}{l}\text { Netherlands De- } \\
\text { fence Academy } \\
\text { (three person } \\
\text { team) }\end{array}$ & $\begin{array}{l}\text { Basic and Senior } \\
\text { Course Faculty; } \\
\text { Curriculum devel- } \\
\text { opment teams }\end{array}$ & $\begin{array}{l}\text { Nether- } \\
\text { lands }\end{array}$ & Complete \\
\hline 2 & $\begin{array}{l}\text { 5-7 Sep } \\
2010\end{array}$ & $\begin{array}{l}\text { Lecture \& Curriculum } \\
\text { Development Session } \\
\text { II: Leaadership and } \\
\text { Ethics }\end{array}$ & $\begin{array}{l}\text { USAWC (Dr. } \\
\text { Craig Bullis, LTC } \\
\text { Vince Linden- } \\
\text { meyer) }\end{array}$ & $\begin{array}{l}\text { Basic and Senior } \\
\text { Course Faculty; } \\
\text { Curriculum devel- } \\
\text { opment teams }\end{array}$ & $\begin{array}{l}\text { DEEP } \\
\text { (WIF) }\end{array}$ & $\begin{array}{l}\text { Pro- } \\
\text { grammed }\end{array}$ \\
\hline 3 & $\begin{array}{l}11-16 \\
\text { Oct } \\
2010\end{array}$ & $\begin{array}{l}\text { Lecture \& Curriculum } \\
\text { Development Session } \\
\text { III: Defense Manage- } \\
\text { ment \& Economics }\end{array}$ & $\begin{array}{l}\text { Canadian De- } \\
\text { fence Academy } \\
\text { (Dr. Craig Stone) }\end{array}$ & $\begin{array}{l}\text { Basic and Senior } \\
\text { Course Faculty; } \\
\text { Curriculum devel- } \\
\text { opment teams }\end{array}$ & Canada & Working \\
\hline 4 & $\begin{array}{l}\text { Oct } \\
2010 \\
(T B D)\end{array}$ & $\begin{array}{l}\text { NATO Standardization } \\
\text { Orientation (review cur- } \\
\text { riculum for NATO stan- } \\
\text { dards) }\end{array}$ & $\begin{array}{l}\text { NATO Standardi- } \\
\text { zation Agency } \\
\text { (LtCol Petry) }\end{array}$ & Basic Course & NATO & Working \\
\hline 5 & $\begin{array}{l}\text { Nov } \\
2010 \\
\text { (TBD) }\end{array}$ & $\begin{array}{l}\text { Tactical Training Tech- } \\
\text { niques and curriculum } \\
\text { review }\end{array}$ & $\begin{array}{l}\text { Canadian De- } \\
\text { fence Academy }\end{array}$ & Basic Course & Canada & Working \\
\hline
\end{tabular}


In order to implement this significant transformation and growth in Moldova's PME program, the Military Institute was reorganized as the Moldovan Military Academy (MMA) "Alexandru cel Bun" in 2010. The Ministry of Defense and the Ministry of Education formally approved the curricula for the transformed basic course and the new senior officer course in Spring 2011. In September of that year, the MMA successfully launched its new curriculum for first-year cadets in the basic course, who will complete the four-year program in 2015, finishing with Bachelor's degrees. In the same month, they initiated the new senior officer course for twenty students, built on a foundation of Western PME principles. Students will graduate with Master's degrees in December 2012. In addition to the transformed and new curricula, an emphasis on faculty development and the adoption of a major change in teaching techniques and approaches to classroom management represent significant aspects of the MMA's enhanced educational program. Both courses received positive internal assessments from students and faculty. During the most recent annual review and assessment, the transformed basic course and new senior officer course were both assessed as having met all objectives, constituting a model DEEP initiative, with the potential to export expertise to other DEEP efforts.

\section{Keys to Success}

The transformation of the PME program in the Republic of Moldova has occurred in a relatively short period of time, and has been accomplished by a nation that is certainly not endowed with an abundance of resources. The successful development and implementation of the Moldovan Military Academy's PME enhancement program was dependent on several key factors. These included support at the national level; the active engagement of members of the MMA staff and faculty; the multinational nature of the NATO team, and the consistent provision of support by key members of that team; and the incorporation of several important complementary international PME programs.

As was mentioned at the beginning of this article, the desire and commitment to transform military education in the Moldovan Armed Forces began at the top, and despite changes in the political leadership of the nation, that support has never wavered. After the initial NATO assessment visit, the team's recommendations were reviewed with Mr. Vitalie Vrabie, Minister of Defense, and Major-General (MG) Ion Coropcean, Chief of the General Staff. Mr. Vrabie expressed his desire for rapid reform and modernization of the Military Institute, was committed to the full adoption of NATO standards, and indicated that this entire effort was a top priority. Throughout the process it was encouraging to the team that the President, Minister of Defense, and the Secretary of the Security Council remained committed to the program to transform the Military Institute and to provide comparable military education to their officers and civilian security professionals. Just prior to the actual initiation of the new courses by the Academy, Brigadier-General Iurie Dominic, the then-Chief of Defense in Moldova, commented on the overall objective and potential of the Defense Education Enhancement Program, stating that this program is "not just about new curriculum, but about a new way of thinking." Colonel Mihail Buclis, the Commandant of the MMA, was the ideal inter- 
locutor between the staff and faculty of the MMA and his national leadership. Unity of purpose and effort were clearly demonstrated in bringing this program to its full fruition.

The second key factor was the active engagement of the faculty and staff of the Moldovan Military Academy. This program was never characterized as a group of Western military professionals and educators presenting an "approved solution" based on existing PME curricula to a compliant group of Moldovan officers. Quite to the contrary, as was indicated above with respect to the national leadership, the leadership and faculty of the MMA were clearly in charge of and committed to the transformation process. Recognition of the need for change was driven by an awareness of the complex security environment of the twenty-first century, and the requirement for qualified specialists in the areas of state security and defense. Members of the MMA faculty became actively engaged in numerous programs associated with the Partnership for Peace Consortium (PfPC).

As DEEP initiatives began to proliferate and mature, the need for a generic officer PME reference curriculum was clearly evident. The development of this document was predicated on a desire to conform to the needs of Partner nations that would actually adopt portions of this curriculum, and thus faculty members from Partner PME institutions were recruited to help create the reference curriculum. One of the key players in that effort was LTC Sergiu Saramet, Chief of the Combined Arms Faculty at the Moldovan Military Academy. He assisted the pre-commissioning team led by LTC Vince Lindenmeyer, from the U.S. Army War College. The efforts to transform the MMA's basic course, in effect, served as a test case for the utility of the reference curriculum. The Military Academy faculty participated in the development of the PfPC Professional Military Education Reference Curriculum, and the reference curriculum contributed to the success of the MMA program: a true win-win situation. The MMA also hosted several multinational events for the PfPC to include an advanced distributed learning workshop and a teaching methodologies workshop. Active engagement by members of the MMA faculty and staff materially contributed to the success of their program as well as to the furtherance of other DEEP efforts.

The multinational nature of the DEEP-Moldova team from the outset constituted the third key factor. Representatives from six NATO and Partner nations participated in the original assessment, and from that time forward two primary teams were established to provide overall assistance to their counterparts in Moldova. Representatives from the Netherlands Defense Academy, the Czech University of Defense, and the Swiss Military Academy partnered with the MMA faculty, led by LTC Sarament, to develop the transformed curriculum for the basic course. The senior course effort was supported by faculty from the U.S. Army Command and General Staff College and the Romanian National Defense University, and interfaced throughout this effort with LTC Sergiu Plop, Chief of Command and Staff Faculty at the MMA. Ideas and sample curricula from all of these institutions were offered for consideration to the MMA. The predominant role of European PME institutions was particularly critical in working through issues related to the Bologna accreditation process. 
Given the relatively short time period available to complete this transformation, it was also important to maintain as much continuity within the NATO teams as possible to ensure the most efficient delivery of assistance. Principal team members were consistently engaged throughout the two-year development process. Repetitive engagements with the same team members and counterparts build trust, deepen the dialogue, and facilitate the ability of the receiving institution to adopt change and transform. In addition to the two principal teams discussed above, several other nations, including Canada and Latvia, provided subject matter experts to conduct various curriculum development workshops. Another aspect of the multinational nature of this effort was the development of partnership relationships with appropriate Western PME organizations. The most important partnership to date has been with the Romanian National Defense University. This relationship has been critical to the success of this DEEP effort.

The final factor recognizes the importance of a multitude of international and national programs that contribute to professional military education. For a nation that has a relatively small military establishment, like the Republic of Moldova, it is imperative that these nations take advantage of professional military education and training opportunities that are offered by other NATO and Partner nations. In addition to the educational opportunities that have been made available to Moldovan officers in Romania, the International Military Education and Training (IMET) program offered by the United States remains very important. Sending students to foreign military institutions immerses them in language and operational approaches that are virtually beyond replication in a host nation. It is also important for nations supplying these opportunities to provide slots for officers that will return to the MMA or training base to share their recently gained knowledge with a much broader audience. IMET allocations should be balanced between the needs of the operational force and the institutional force. Moldovan officers have also benefited from NATO-wide programs, such as the NATO Defense College and NATO School, and the Higher Command Studies Course at the Baltic Defense College. All of these programs are an important supplement to Moldovan PME courses.

The two principal sources of support for scheduling, recruitment, and funding of the DEEP have been the PfPC at the George C. Marshall Center, and the Defense Education Programs section of the NATO International Staff. From a U.S. perspective it is also important to coordinate DEEP activities with the country team at the Office of Defense Cooperation (ODC) and the Defense Attaché. The ODC has provided invaluable support for the full range of DEEP activities. One important aspect of this cooperative arrangement was the linkage of the DEEP initiative to the USEUCOM Country Campaign Plan. As a result, additional activities were scheduled and funded, over and above those supported by the PfPC. It is also imperative that all interested parties - including EUCOM, the Defense Security Cooperation Agency, and the pertinent offices in the Department of Defense- - be informed and engaged in the support of the DEEP. Synchronization across all of these entities greatly facilitated the execution of the program. 


\section{Sustaining the Transformation}

As the MMA continues to implement changes to the basic course and prepares to review and plan for the second iteration of the senior officer course, it remains important for the various organizations that support DEEP to continue to provide assistance to sustain the progress that has already been made. As depicted on the long-range plan, DEEP initiatives are generally designed for three years, at which time host nations are assumed to be in a position of self-sufficiency. Although these programs certainly mature, self-sufficiency is neither a desired nor realistic goal. Multinational operations and intergovernmental activities are integral to successful military and security activities, and thus they should remain a critical part of PME institutions. DEEP partners and supporting organizations should continue to support the MMA and other DEEP nations with subject matter experts who are available to conduct lectures and curriculum development sessions. These sessions reinforce the importance of PME programs to the host nation students and leadership, and make an invaluable contribution to the education of these military officers and national security professionals. Equally important is to continue the emphasis on faculty development. All PME institutions will experience faculty turnover, and thus it is incumbent on organizations supporting DEEP efforts to continue to conduct teaching methodology workshops. Retention and recruitment of quality faculty is probably the center of gravity for the long-range success of these programs, and continued involvement with DEEP-related programs will help in this effort.

DEEP efforts have been focused on the development of intellectual interoperability, and have thus concentrated on what to teach and how to teach. But as these programs mature, other educational needs should be addressed. Most of the DEEP recipient nations lack adequate library resources to support the full range of Western-oriented PME courses. Other educational resources, such as classroom technology and certain infrastructure requirements, may not be up to the standards necessary to support an adequate learning environment. These types of resources are not within the scope of DEEP, but some alternative means should be developed to address the most critical shortfalls. In the case of the MMA, the Swiss government provided library assistance to expand their collection of books and materials related to professional studies, military history, and geopolitics. Major supporting organizations, including the NATO International Staff and the PfPC, should develop approaches to identify needs and appropriate donors.

\section{Conclusion}

DEEP-Moldova has been focused on developing the institutional capacity of the Moldovan Military Academy to provide high-quality military education to a younger generation of officers that will contribute to building a sustainable and secure society. Incorporation of Western-oriented professional military education subjects will contribute to the professionalization of the Moldovan Armed Forces' officer corps. The reform of the Moldovan military education system, to include improved curricula and teaching methodologies, will contribute to the complete transformation of their military. Such a transformation will lead to sound decision making on the part of future military leaders, 
greater participation and cooperative capability with NATO and EU forces, and strengthened relationships between the Republic of Moldova and NATO members and Partners. In a broader sense, this effort supports the NATO Education and Training for Defense Reform Initiative and the U.S. Warsaw Initiative Fund (WIF) focus area on defense institution building and professional defense education. The DEEP initiative represents a cost-effective application of limited resources, and has leveraged the contributions of a multitude of nations to assist the MMA in reaching their educational goals. The importance of continuing to sustain these efforts cannot be over-emphasized. Sustained support of the MMA will produce enduring long-term results, establishing a firm professional foundation for the armed forces of the Republic of Moldova. 
THE QUARTERLY JOURNAL

\section{Bibliography}

Dempsey, Martin. Chairman's Corner: Strategic Direction to the Joint Force., 2012.

Gates, Robert M.. "Helping Others Defend Themselves: The Future of U.S. Security Assistance." Foreign Affairs (2010). 